\title{
A proposed model of e-trust for electronic banking
}

\author{
Neda Yousefi ${ }^{\mathrm{a}}$ and Amir Ashkan Nasiripour ${ }^{\mathbf{b}^{*}}$
}

${ }^{a}$ Department of Information Technology Management, Science and Research Branch, Islamic Azad University, Tehran, Iran ${ }^{b}$ Associate Professor, Department of Health Services Management, Science and Research Branch, Islamic Azad University, Tehran, Iran

\section{H R O N I C L E}

\begin{tabular}{l}
\hline Article history: \\
Received March 25, 2015 \\
Received in revised format \\
August 62015 \\
Accepted August 172015 \\
Available online \\
August 182015 \\
\hline Keywords: \\
Trust \\
Customer \\
E-Banking
\end{tabular}

\section{Introduction}

In recent years, the growth of information technology has created a revolution in human life and performance of organizations. The banking industry also strongly is influenced by information technology and consequently, the Iranian banks, in carrying out their activities, largely use of new information technologies (Barooti Ardestani, 2006). The progress of electronic communication, and to follow the disappearance of distances in time and space, and the access of a large number of people to the worldwide web, have created a good platform for the establishment of trade and economic exchanges. This has caused an increase in competition in the banking industry, and has provided electronic banking services. In such circumstances, there is a need for trust, more than ever, and in the intense competition, those banks will be successful which have created more trust among their own customers to use electronic services (Khaksar \& Giahi, 2009). Trust is a complex and abstract concept, it is difficult to define trust and to identify the elements that construct it. On the other hand, lack of trust has been repeatedly identified as one of the most formidable barriers to people for engaging in Ebanking services. In fact, to acquire and to retain online customer as well as to build competitive advantage in e-banking space, the electronic services providers should be creating and maintaining a climate of trust (Kamari et al., 2012). According to what was said, timely detection the extent of * Corresponding author. Tel: +98-912-1991372

E-mail address: nasiripour@srbiau.ac.ir (A. A. Nasiripour) 
customer's trust in e-banking services, and effective factors on it, from both of theoretical and practical aspects are considered as essential factors. Thus, the goal of the present research is to investigate the factors affecting customer's trust in E-banking services and prioritize them. The findings of this paper will provide the practitioners and researchers with a set of manageable and strategic levers to build such trust, which will promote greater acceptance of electronic banking and financial services, and also help banks provide more customer-oriented services and developing e-competitive advantage. To do this study, first we explain its related literature review and provide a conceptual model. Then we investigate the formulation of hypotheses and data analysis. At the end, we explain the research conclusions.

\section{Theoretical foundations of research}

\subsection{E-Banking}

Nowadays, the electronic technology is playing a major role for the world of business especially in banking activities. Electronic banking (e-banking) is the newest delivery channel for banking services. The definition of e-banking varies amongst researches partially because electronic banking refers to several kinds of services through which bank customers may ask information and perform most retail banking services via computer, mobile phone, etc. (Daniel, 1999; Mols, 1998; Sathye, 1999). In fact, ebanking is effectively "opened" twenty-four hours a day, seven days a week. Customers may execute their daily banking activities without having to wait in line. E-banking gives electronic services that help consumers check the balances in their accounts, transfer funds among accounts, pay bills electronically as well as apply for loans, download information about accounts into their own computers, trade stocks or mutual funds, look at images of their cheques and deposit slips (Turban et al., 2000). E-banking has become increasingly necessity, implemented by several financial institutions to reduce unnecessary expenses associated with having personnel serve customers physically, shorten processing periods, increase speed, improve the flexibility of business transactions and give better service overall (Shih \& Fang, 2004). In addition, with the rapid progress of other kinds of electronic, largely Internet based services; there has been increased trend in e- banking services. With the rapid growth of Internet technology, online banking has played an essential role in the e-payment area which offers an online transaction platform to support many e-commerce applications such as online shopping, online auction and Internet stock (Nasri et al., 2011). In this study, the order of E- banking is providing customer's access to banking services by using safe channels and without physical presence.

\subsection{Trust}

The history of trust goes back to human beings and almost every aspect of a person's life relies on some forms of trust. Trust, according to the Oxford English Dictionary (1971), is defined as " confidence in or reliance on some quality or attribute of a person or thing, or the truth of a statement"' (p. 3423). Urban et al. (2009) defined trust as "the belief that another is benevolent, competent, honest, or predictable in a given situation." Trust as an important factor to facilitate the online transactions and it is also considered as one of the main success factors of e-commerce and e-banking. The issue of trust in e-banking environment is more essential than traditional banking environment since when uncertainties and risks are pervasive, the building and developing the trust will become more crutial (Urban et al., 2009; McKnight et al., 2002). Trust in online space is defined as "the subjective assessment of one party that another party will perform a particular transaction according to his or her confidant expectation, in an environment characterized by uncertainty" (Ba \& Pavlou, 2002). Lack of trust is stated as the biggest barrier preventing consumers from transacting online (Corbitt \& Thanasankit 2003; Corbitt et al., 2003). Despite the lack of a good definition of the meaning of trust, the online trust was defined as the "willingness of a party to be vulnerable to the action of another party based on the expectation that the other will perform a particular action important to the trustor, irrespective of the ability to monitor or control that other party”. (Mayer et al., 1995), According to what mentioned, trust is determined by the trustor's propensity to trust in ability, benevolence, and 
integrity of the trustee. (Ahmadi Khorram, 2010). Therefore, it can be concluded that due to the expansion and growth of the internet and e-commerce, trust is one of the most important elements in improvement, development and success of e- banking. In this study, the measured parameters of this variable are as follows: Integrity (the perception that the trustee adheres to a set of principles that the trustor finds acceptable.), ability/competence (the bank's ability to perform the promised services), and benevolence (the extent to which the trustee is believed to want to do good to the trustor aside from an egocentric profit motive.)

\subsection{Quality of E-banking services}

According to Cho and Hu (2009), the quality of the service presented by a loan giver in financial institutes has a positive effect on building trust among the customers toward the institutes from which they took the loan. In addition, according to Kassim and Abdullah (2010), understanding the service quality has a notable effect on customer satisfaction. In turn, customer satisfaction has a significant effect on trust. Mircholi et al. (2012) reported that the quality of e-banking services had effects on the electronic trust. According to the above points, it is clearly evident that feature of e-service quality has direct and indirect effect on customer's e-satisfaction and e-trust in e-banking services (Ghane et al., 2011), and attention to this affair is important for banks seeking to build consumer trust on the online space. Many criteria have been discussed by academic researchers, in this study, perceived ease of use, perceived usefulness, perceived privacy and perceived security have been considered as the dimensions of quality of banking services:

- Ease of Use: Perceived ease of use can be described as the extent to which a person believes that using a specific system would be free of effort (Lichtenstein \& Williamson, 2006). The Measured parameters of this variable are as follows: time savings and availability and the speed of providing banking services.

- Usefulness: Davis et al. (1989) referred to perceived usefulness as the degree to which a person believes that applying a specific system will enhance his/her performance. Measured parameters of this variable are as follows: customer's perception that using e-banking services, will improve their performances as well as the extent to which e-banking services will be essential for customers.

- Perceived privacy: perceived privacy, as defined by Yousafzai et al. (2003) is "the consumer's ability to control (a) presence of other people in the environment during a market transaction or consumption behavior, and (b) the dissemination of information related to or provided during such transactions or behaviors to those who were not present.”. Control over information, is a primary key dimension of privacy and has been stressed by researchers in diverse disciplines. Consequently, for this research measured parameters of perceived privacy can be described as: customer's perception of regarding their ability to monitor and control the information about themselves, Prevent disclosure and Unintended use of customer information via the Internet and decisive encounter with all forms of abuse of costumer's personal information by the bank's.

- Perceived security: Security is being defined as "a threat which creates circumstance, condition, or event with the potential to cause economic hardship to data or network resources in the form of destruction, disclosure, modification of data, denial of service, and/or fraud, waste, and abuse" (Kalakota \& Whinston, 1997). The measured parameters of this variable are as follows: customer's perception of the degree of bank's protection against unintended or unauthorized access, change or destruction of the information and also the bank 's usage of technologies that have been developed for securing electronic transactions such as cryptographic techniques and methods

$\mathrm{H}_{1}$ : Quality of e-banking services influences on increasing of customer's trust in e-banking services

\subsection{Web sites features}

Wang and Emurian (2005) paid attention to the role and importance of factors related to the web design in constructing consumer trust on the Internet space. According to the framework that presented by 
Wang and Emurian (2005), in this study, graphic design, structure design, content design, and socialcue design are considered as the dimensions of Web sites features:

- Graphic design: This is associated with the graphical design factors on the web site that normally give consumers a first impression. The measured parameters of this variable are as follows: Use of three-dimensional, dynamic and half-screen size clipart, Symmetric use of moderate pastel color of low brightness and cool tone and Use of well-chosen good-shot photographs.

- Structure design: Defines the overall organization and accessibility of displayed information on the web site. The measured parameters of this variable are as follows: Implementation of easy-to-use navigation (simplicity, consistency), Use of accessible information (e.g., no broken links and missing pictures), Application of page design techniques (e.g., white space and margin, strict grouping, visual density).

- Content design: Refers to the informational components that can be included on the web site, either textual or graphical. The Measured parameters of this variable are as follows: Use of comprehensive, correct, and current information on web site, Use of guides, tutorials and instructions on website, Up-front disclosure of all aspects of the customer relationship.

- Social-cue design: Relates to embedding social cues, such as face-to-face interaction and social presence, into web interface via different communication media. The measured parameters of this variable are as follows: Inclusion of representative photograph or video clip, Use of synchronous communication media (e.g., instant messaging, chat lines, video telephony).

$\mathrm{H}_{2}$ : Website features influence on increasing of customer's trust in E-banking services

\subsection{Bank features}

According to Teo and Liu (2007) and also Delafrooz et al. (2013), the characteristics of the trustee (provider of banking services), such as the perceived size, perceived reputation and system assurance have positive relationship with the level of customer's trust in e-business environment and consequently, e-banking. With regarding to the mentioned studies, in this research, the bank features' aspects are including of: Bank reputation, bank’s governmental dependence and bank’s size.

- Reputation: points to mental images about the organization actually protected by others outside the organization (Walsh et al., 2009). When customers have no experience with a special company, reputation may be the key to absorb customers. According to Ha (2004), reputation is a critical component of trust. The measured parameters of this variable are as follows: positive Performance of bank in the past and other people's Word- of- mouth advertising, about the e-services of this bank.

- Size: The Bank's size is defined as the overall size and its position on a marketplace (Doney \& Cannon, 1997). The measured parameters of this variable are as follows: the number of branches and the wide geographic coating in the inside and outside of the country in providing services.

- Dependency on government: The measured parameters of this variable are as follows: Customer's preferences to use from electronic services of State bank s or the banks that are dependent on government agency.

$\mathrm{H}_{3}$ : Bank’s features influence on increasing of customer’s trust in E-banking services.

\subsection{Individual characteristics of customers (trustors)}

Sultan et al. (2002) in their studies showed that customer's perception of trust in e-business is associated with the consumer characteristics including demographics, previous Web site experience and knowledge of how to use the internet. And also by examining the antecedents and consequences of consumer trust in electronic business, Teo and Liu (2007) showed that the feature of the Trustor (the 
customer) like the disposition to trust, have significant effect on customer trust in e-business. In this study, the dimensions of individual characteristics of customers are demographic characteristics (such as age, sex, occupation, education and income), disposition to trust and previous experience of working with the Internet and using Electronic services.

- Disposition to trust: in terms of trustor attributes, disposition to trust is the general willingness to trust other people and a measure of an individual's tendency to trust or distrust (Teo \& Liu, 2007). People with a trusting disposition tended to be more trustworthy than others. The measured parameters of this variable are as follows: individual's belief that, others are generally reliable and dependable.

- Experience in working with Internet: The measured parameters of this variable are: having knowledge and experience in the use of Internet and proficiency in the use of e-banking services.

$\mathrm{H}_{4}$ : Individual characteristics of customer influence on increasing of customer's trust in e-banking services.

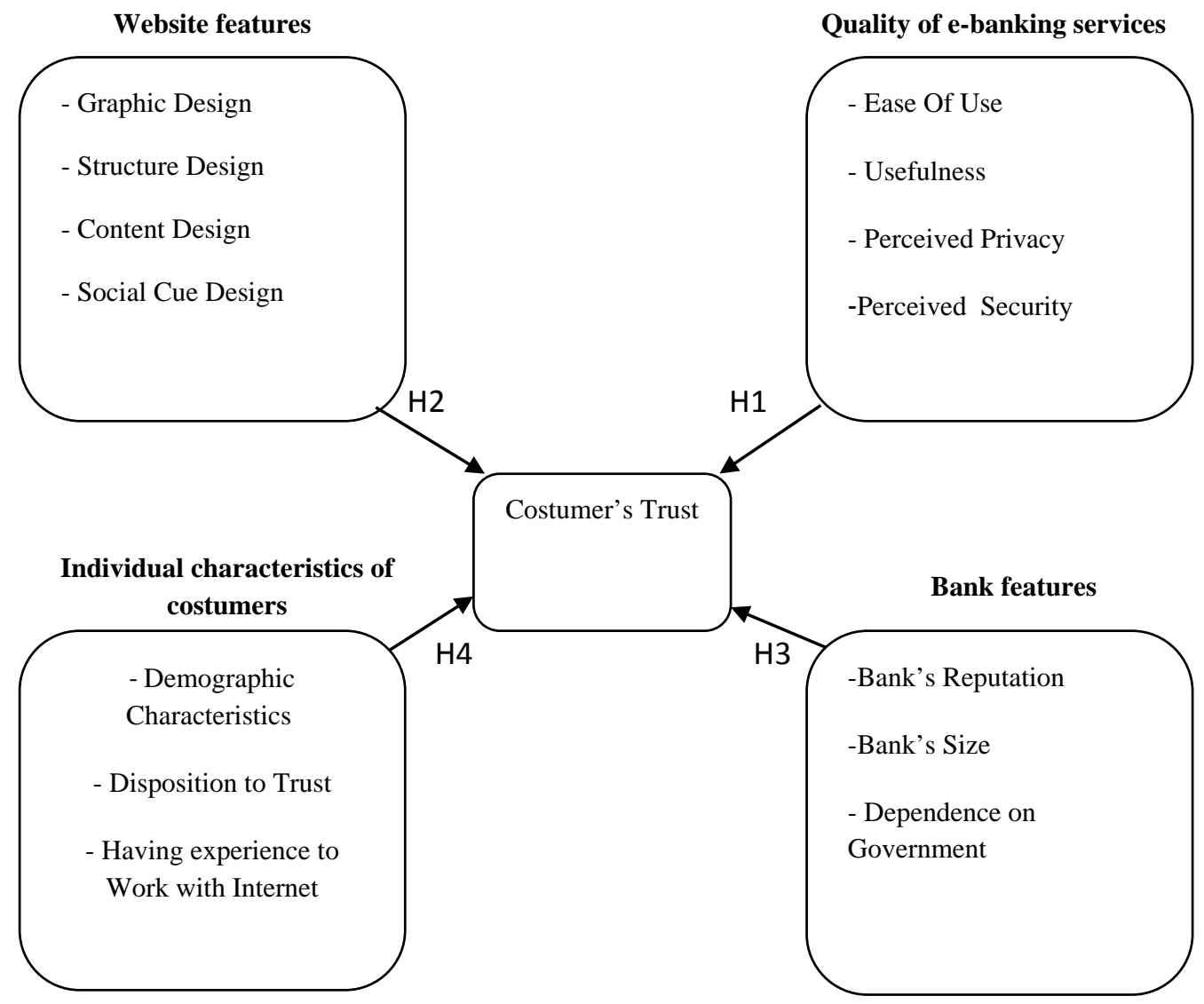

\section{Materials and methods}

Fig. 1. Research model

This research, from the point of view of goal, is practical, and from the method and nature point of view is categorized with the descriptive-co relational. This research, first with the use of library sources, studied and skimmed literature of the subject. Then a two-part questionnaire consisting of demographic characteristics and main body was designed. All items in this questionnaire were scored on a five point Likert-type scale ranging from (1) Strongly Disagree to (5) Strongly Agree. The statistical population is E-banking customers of some banks in Karaj, Iran such as Melat, melli, Saderat, Pasargad, Parsian and Saman in the period of the research (from March 2014 to July 2014). The sample size 177 was determined by using of simple random sampling method. After designing the questionnaires based on the theoretical foundations, this questionnaire was evaluated by university professors, and then their comments and proposed corrections were applied in this questionnaires. The most typical way of 
evaluating reliability is Cronbach's Coefficient Alpha inner consistency. Cronbach Alpha is used for questions with multi scale categories. For evaluating this questionnaire's perpetuity, Cronbach Alpha is used, the total Cronbach Alpha is equal to 0.771. In this paper, for data analysis, structural equation modeling approach was used (LISREL ${ }^{1}$ ). Structural equation modeling approach is divided into two parts: the first part explains the relationship between latent variables (factor) and observer variables (markers) and in the second part, the relationship between endogenous and exogenous latent variables to evaluate the casual relationship and their effects, were examined. In most cases, the maximum likelihood (ML) method used to estimate coefficients (Mishra et al., 2010). Before testing the hypotheses, confirmatory factor analysis has been used for questionnaire's internal validity. Also to answer the question if the presented model by data confirms the research measurement model or not, Fitting Indexes such as : $\mathrm{RMSEA}^{2}, \chi^{2} / \mathrm{df}^{3}, \mathrm{NFI}^{4}, \mathrm{GFI}^{5}$ and $\mathrm{AGFI}^{6}$, were used. Acceptance criteria for these indexes include: $\chi 2$ / df $<3$, RMSEA $<0.08$, AGFI $>0.90$, GFI $>0.90$, NFI $>0.90$.

\section{Results}

The results show that the factor loading for each variable is above 0.5 , which indicates a good correlation between the observer variables with latent variables. In addition, according to the results, all fitting indexes are satisfying and show general model’s acceptability. (see Table1).

\section{Table 1}

Confirmatory factor analysis for research variables

\begin{tabular}{|c|c|c|c|c|c|c|c|c|c|}
\hline \multirow{2}{*}{ Factor } & \multirow{2}{*}{ variable } & \multirow{2}{*}{ indexes } & \multirow{2}{*}{$\begin{array}{c}\text { Factor } \\
\text { Loading }\end{array}$} & \multirow{2}{*}{ AVE } & \multicolumn{5}{|c|}{ Fitting Indexes } \\
\hline & & & & & $\chi^{2} / \mathrm{df}$ & RMSEA & AGFI & GFI & NFI \\
\hline \multirow{9}{*}{$\begin{array}{l}\text { Quality of } \\
\text { E-Banking } \\
\text { Services }\end{array}$} & \multirow{2}{*}{ Ease of Use } & EASE1 & 0.78 & \multirow{2}{*}{0.7} & \multirow{9}{*}{$15.61 / 12$} & \multirow{9}{*}{0.041} & \multirow{9}{*}{0.96} & \multirow{9}{*}{0.98} & \multirow{9}{*}{0.98} \\
\hline & & EASE2 & 0.9 & & & & & & \\
\hline & Usefulness & USEF1 & 0.86 & 059 & & & & & \\
\hline & useiumlits & USEF2 & 0.67 & 0.59 & & & & & \\
\hline & Perceived privacy & PRI1 & 0.94 & 062 & & & & & \\
\hline & Percerveu privacy & PRI2 & 0.6 & 0.02 & & & & & \\
\hline & \multirow{3}{*}{ Perceived security } & SEC1 & 0.74 & \multirow{3}{*}{0.55} & & & & & \\
\hline & & SEC2 & 0.74 & & & & & & \\
\hline & & SEC3 & 0.74 & & & & & & \\
\hline \multirow{11}{*}{$\begin{array}{l}\text { Website } \\
\text { Features }\end{array}$} & \multirow{3}{*}{ Graphic design } & PHY1 & 0.88 & \multirow{3}{*}{0.71} & \multirow{11}{*}{38.98 / 38} & \multirow{11}{*}{0.012} & \multirow{11}{*}{0.93} & \multirow{11}{*}{0.96} & \multirow{11}{*}{0.96} \\
\hline & & PHY2 & 0.82 & & & & & & \\
\hline & & PHY3 & 0.81 & & & & & & \\
\hline & Content desion & CON1 & 0.57 & 0.67 & & & & & \\
\hline & conitent uesignt & CON2 & 1.01 & 0.07 & & & & & \\
\hline & & STR 1 & 0.63 & \multirow{4}{*}{0.6} & & & & & \\
\hline & \multirow{3}{*}{ Structure design } & STR 2 & 0.87 & & & & & & \\
\hline & & STR 3 & 0.87 & & & & & & \\
\hline & & STR 4 & 0.7 & & & & & & \\
\hline & \multirow{2}{*}{ Social cue design } & SOC1 & 0.54 & \multirow{2}{*}{0.86} & & & & & \\
\hline & & SOC2 & 1.19 & & & & & & \\
\hline & Reputation & REP1 & 0.54 & 077 & & & & & \\
\hline & керutation & REP2 & 1.12 & 0.17 & & & & & \\
\hline Bank features & dependence on government & PUB1 & 0.81 & 0.74 & $792 / 6$ & 0.043 & 0.98 & 0.99 & 0.99 \\
\hline Dallk ledtures & аерепाuence on govenmint & PUB2 & 0.91 & 0.14 & 1.9210 & 0.040 & 0.90 & 0.99 & 0.99 \\
\hline & Size & SIZE1 & 0.75 & 0.6 & & & & & \\
\hline & SILE & SIZE2 & 0.8 & 0.0 & & & & & \\
\hline & & DIS.TR1 & 0.85 & & & & & & \\
\hline Individual & Disposition to trust & DIS.TR2 & 0.94 & 0.75 & & & & & \\
\hline characteristics & & DIS.TR3 & 0.79 & & $4.33 / 4$ & 0.022 & 0.99 & 1 & 1 \\
\hline of costumers & Having Experience To & EXP1 & 0.93 & 07 & & & & & \\
\hline & Work With Internet & EXP2 & 0.74 & 0.1 & & & & & \\
\hline
\end{tabular}

\footnotetext{
${ }^{1}$ Linear Structural Relation

${ }^{2}$ Root Mean Square Error of Approximation

${ }^{3}$ Chi-square Index divided by the Degrees of Freedom

${ }^{4}$ Nor med Fit Index

${ }^{5}$ Goodness of Fit Index

${ }^{6}$ Adjusted Goodness of Fit Index
} 
In this study, path analysis method was used to examine the research hypothesis. According to table 2, Results show that all the hypotheses except the second hypothesis were confirmed ,because the Tvalue (Significant coefficients) for second hypothesis, is below 1.96. (the hypothesis will be confirmed if the "Significant coefficients" is smaller than -1.96 or greater than 1.96.).

Also The output of the software indicates the suitability of the structural model fitted to hypotheses testing. ( $\chi^{2} / \mathrm{df}$, is less than 3 , ( $\left.3>127.45 / 94\right)$, the RMSEA is equal to 0.045 , and the values of AGFI, GFI and NFI, are, 0.90, 0.92 and 0.95 respectively.)

Table 2

Examining the research hypotheses

\begin{tabular}{lccc}
\multicolumn{1}{c}{ Hypotheses } & $\begin{array}{c}\text { Standardized } \\
\text { estimated } \\
\text { coefficients }\end{array}$ & $\begin{array}{c}\text { Significant } \\
\text { Coefficients }\end{array}$ & $\begin{array}{c}\text { confirmation } \\
\text { or rejection }\end{array}$ \\
\hline $\begin{array}{l}\text { 1: Quality of e-banking services influences on increasing of customer's trust } \\
\text { in E-banking services }\end{array}$ & 0.42 & 3.11 & $\checkmark$ \\
$\begin{array}{l}\text { 2: Website features influence on increasing of customer's trust in E-banking } \\
\text { services }\end{array}$ & 0.07 & 0.57 & $\times$ \\
$\begin{array}{l}\text { 3: Bank features influence on increasing of customer's trust in E-banking } \\
\text { services } \\
\begin{array}{l}\text { 4: Individual characteristics influence on increasing of customer's trust in E- } \\
\text { banking services }\end{array}\end{array}$ & 0.43 & 4.19 \\
\hline
\end{tabular}

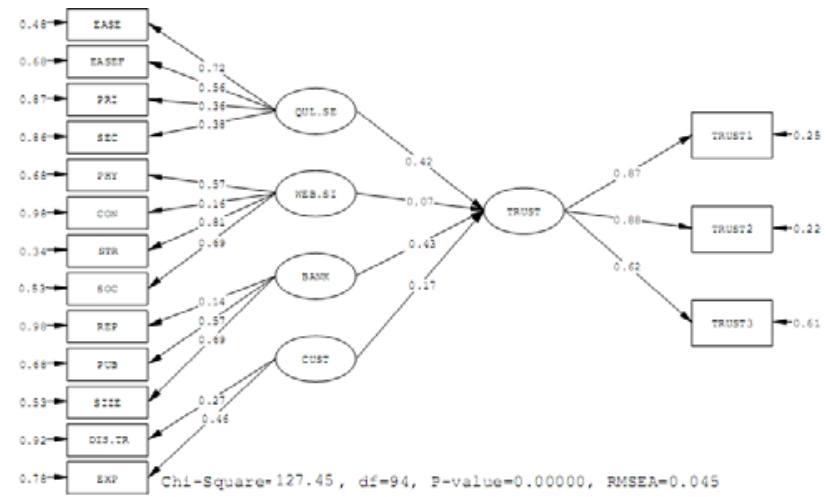

Fig. 2. The structural equation modeling in state of "Standardized estimated coefficients"

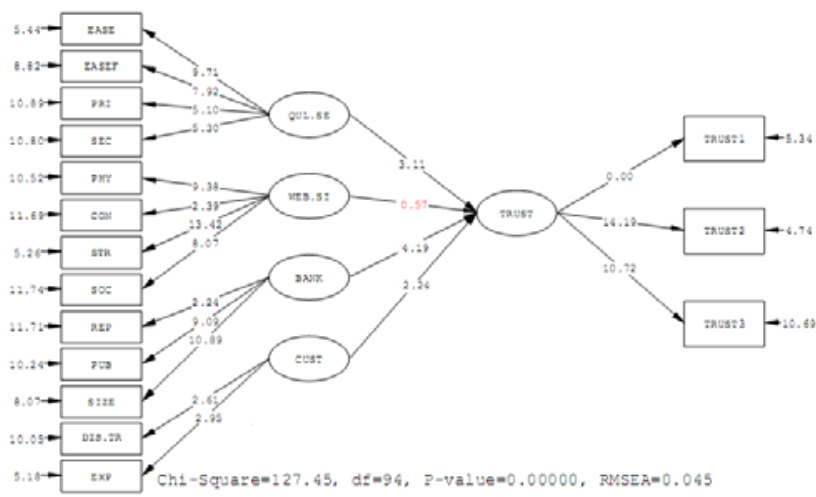

Fig. 3. the structural equation modeling in state of "Significant coefficients"

The analysis of associated variables of each factor has indicated that the variables related to bank's reputation, dependence on government and security have the most influence $(67 \%, 54 \%$ and $45 \%$, respectively) on customer's trust in electronic banking services (See Table 3).

\section{Table 3}

The effect of associated variables of each factors on customer's trust

\begin{tabular}{|c|c|c|c|}
\hline The effect of variables on increasing of customer's trust & $\begin{array}{c}\begin{array}{c}\text { Standardized path } \\
\text { coefficients }\end{array} \\
\end{array}$ & $\begin{array}{c}\begin{array}{c}\text { Significant coefficients } \\
\text { (T-value) }\end{array} \\
\end{array}$ & $\begin{array}{c}\text { confirmation or } \\
\text { rejection }\end{array}$ \\
\hline The effect of ease of use on increasing of customer's trust & 0.22 & 2.52 & $\checkmark$ \\
\hline The effect of Usefulness on increasing of customer's trust & 0.09 & 1.04 & $x$ \\
\hline The effect of perceived privacy on increasing of customer's trust & 0.29 & 3.52 & $\checkmark$ \\
\hline The effect of perceived security on increasing of customer's trust & 0.45 & 4.76 & $\checkmark$ \\
\hline The effect of Graphic design of website on increasing of customer's trust & -0.03 & -0.41 & $x$ \\
\hline The effect of Content design of website on increasing of customer's trust & 0.11 & 2.12 & $\checkmark$ \\
\hline The effect of Structure design of website on increasing of customer's trust & 0.23 & 2.84 & $\checkmark$ \\
\hline The effect of Social cue design of website on increasing of customer's & -0.02 & -0.28 & $x$ \\
\hline The effect of bank's Reputation on increasing of customer's trust & 0.67 & 6.48 & $\checkmark$ \\
\hline The effect of bank's Dependence on Government on increasing of & 0.54 & 4.99 & $\checkmark$ \\
\hline The effect of bank's Size on increasing of customer's trust & 0.21 & 2.34 & $\checkmark$ \\
\hline The effect of Disposition to trust on increasing of customer's trust & 0.40 & 3.81 & $\checkmark$ \\
\hline The effect of Having Experience To Work With Internet on increasing of & 0.01 & 0.12 & $x$ \\
\hline
\end{tabular}


Also, in terms of each of the variables related to three accepted factors (quality of e- banking services, Bank features and Individual characteristics of costumers), the effects of 'usefulness' and 'the experience to work with Internet' on customer's trust were not confirmed. In addition, Since the demographic variables can't be measured with the Likert scale, so to investigate their roles on customer's trust, method of one-way ANOVA were used. (Table 4).

\section{Table 4}

Analyzing the trust of customers according to demographic variables

\begin{tabular}{cccc}
\hline Demographic variables & Man & $\begin{array}{c}\text { The average value of } \\
\text { customer's trust, according to } \\
\text { demographic variables }\end{array}$ & (Sig) \\
\hline $\begin{array}{c}\text { Gender } \\
\text { groups }\end{array}$ & Woman & 3.93 & 0.777 \\
\hline Age & $<20$ years & 3.96 & 0.33 \\
groups & $21-25$ years & 4 & \\
\hline & $26-30$ years & 3.95 & 0.999 \\
\hline Educational groups & $31-40$ years & 3.97 & 3.92 \\
\hline & $>41$ years & 3.97 & 3.95 \\
\hline Job & Diploma & 3.95 & 3.93 \\
\hline groups & Associate Degree & 3.98 \\
& Bachelor's degree & 4.06 & 0.131 \\
\hline & Masters & 3.94 \\
\hline
\end{tabular}

The result of variance analysis showed that there was no significant difference in terms of trust between Gender Groups, Age groups, Educational groups, job groups and Income groups. Therefore it can be said that there was no significant relationship between customer's trust and demographic variables.

\section{Discussion and Conclusion}

The results have revealed that among hypotheses, the effects of Web sites features on increasing of customer's trust in the electronic banking service were rejected but other hypotheses were confirmed. Also among the examined factors, the bank feature's aspects (reputation, size and dependence on government) have had the greatest effect on customer's trust (\%43) and quality of electronic services (ease of use, privacy and security) and Individual characteristics of costumers (Disposition to trust) with $42 \%$ and $17 \%$, respectively were after that.

The analysis of associated variables of each factor were indicated that the variables related bank's reputation, dependence on government and security have the most influence $(67 \%, 54 \%$ and $45 \%$, respectively) on customer's trust in electronic banking services (Table 3). Also, in terms of each of the variables related to three accepted factors (quality of E-banking services, Bank features and Individual characteristics of costumers), the effect of 'usefulness' and 'the user 's experience to work with Internet' on customer's trust were rejected. In addition, the significant relationship between demographic characteristics and consumer trust in e-banking services was not confirmed. The effect of quality of e-banking services on increasing of customer trust in services were confirmed. This may be due to the close relationship between customer satisfaction of e-banking services quality and the level of customers' trust, which means that services with higher quality result in customer's e-satisfaction 
and e-trust in E-banking services. This finding is in line with results of Kassim and Abdullah (2010), and Mircholi et al. (2012).

Also, between components (variables) of this factor, the effect of perceived usefulness on trust was rejected, which is not aligned with results of Chirani et al. (2011). But the effects of the other 3 components of this factor, namely, perceived security, perceived privacy and ease of use on trust were confirmed, which are consistent with the findings of Al-Hawari (2011), Yousafzai et al. (2003), and Abedi et al. (2013) respectively.

According to this findings it could be suggested to the management of bank services that they should optimize the bandwidth of their servers (by having several special IP address simultaneously, DNS (Domain Name System) and powerful CMS(Content Management System)).also bankers need to concentrate and continually improving the security and privacy issues of their offered e-services, by using safety mechanism and technologies to prevent a third party from unauthorized access, use, alteration, or destruction on-line customers' information such as Firewalls, Public Key infrastructure, Encryption software, Digital certificates, Digital Signatures, Biometrics (retinal scan, fingerprints, voice, etc.) and secure protocols (SSL, SET, etc.). In addition, it is recommended to the management of banks that state the security and privacy policy clearly in their sites and describe the measures taken to ensure that data is transferred, processed and stored securely and also states what personal information is collected, how it will be used within the bank and whether it will be sold to other companies and their site should contains information about customer redress mechanisms or financial compensation in case of fraud and unauthorized access.

The above-mentioned cases are effective steps to gain customers' trust in services results of the second hypothesis showed that the effect of web site feature on increasing customer trust in e-banking services was rejected which is different from results of Wang and Emurian(2005) and Sanayei et al. (2010). One possible explanation for the lack of support for the positive relationship between web site features and consumer trust could be that the most consumers do not have awareness about capabilities and facilities of sites. Despite the rejection of second hypothesis, the effect of content design and structure design of website on the customer trust were confirmed. In this regard, it is recommended to banks to update their website contents and provide sufficient and useful information to their customers to fulfill the online transaction and also the bank's Web site should be displayed in most browsers and Navigation across different sections of the sites should be consistent. Also, navigation reinforcement, such as prompts, guides, tutorials, and instructions, could aid and inform users to seek information or to perform transactions on the web site easily. In other words, when the structure and content design of the web site are consistent, "users feel more confident using the site" and, hence, promoted consumer trust. Results of the third hypothesis showed that the bank features, (reputation, size and dependence on government), is effective on increasing of customer trust in e-banking services, which is aligned with results of Delafrooz et al. (2013), Teo and Liu (2007), and Kameri et al. (2012).

According to the above points, it can be said that the large size of bank indicates that the bank is likely to possess expertise and necessary support systems that encourage trust and loyalty. Larger banks also tend to have well-developed Web sites to encourage transactions. Finally, in an e-banking environment, large size (the large number of branches) indicate the strength and stability of a bank. Therefore it is recommended to banks to increase their coverage areas.

On the other hand, the reputation might be particularly important for those banks who are not the largest in their field. Without an indication of large perceived size, prospective customers can be expected to be especially interested in a bank's reputation. Therefore, less well-known banks should be able to build and promote their reputations by describing their history (older being presumably better) and by quoting their policies for customer satisfaction. Also about the impact of governmental dependency on 
customer trust, one possible explanation could be that the government by having high capital and strength, could protect the customers against any event that occur in banks. Therefore, it is suggested to the banks not to have governmental dependency in order to increase the customers' trust using the effective promotional methods and offering distinctive advantages to their online customers.

Results of the fourth hypothesis showed that individual characteristics of customers particularly disposition to trust, are effective on increasing their trust in the e-banking services, which is aligned with results of Teo and Liu (2007).

In fact, among the variables related to individual customers' characteristics, the impact of the user's Internet experience on trust in e-banking services was rejected and we did not find any significant relationship between demographic variables and trust, which are not compatible with the results of Sultan (2002).

\section{Acknowledgement}

The authors would like to thank the anonymous referees for constructive comments on earlier version of this paper.

\section{References}

Abedi, H., Seyedi, A. \& Bakhshan, M. (2013). Identify and prioritize factors influencing customers' trust in Internet banking. Bank marketing articles.

Ahmadi Khorram, S. (2010). Prioritization of factors related to customer trust in electronic services of Eghtesad Novin bank in Tehran. Master's Thesis, Tehran: Allameh Tabataba'i University, Faculty of Management and Accounting. [Persian]

Al-Hawari, M. A. (2011). The Role of Bank Automated Services in Gaining Customers' Trust: A Practical Study in UAE. Jurnal Pengurusan, 33, 45-52.

Azar, A., \& Momeni, M. (2009). Statistics and Applications in Management. Tehran: SAMT Publications.

Ba, S., \& Pavlou, P. A. (2002). Evidence of the effect of trust building technology in electronic markets: Price premiums and buyer behavior. MIS quarterly, 26(3), 243-268.

Barooti Ardestani, N. (2006). Developing a conceptual model of information technology for banking system Personnel, Case Study: Saderat Bank Personnel in Tehran. Master's Thesis, Tehran: Alzahra University, Faculty of Engineering. [Persian]

Chirani, A. \& Tahery, T. (2011). Factors affecting customer trust, Case Study: Melli Bank in Ardabil. Master's Thesis, Iran.

Cho, J. E., \& Hu, H. (2009). The effect of service quality on trust and commitment varying across generations. International Journal of Consumer Studies, 33(4), 468-476.

Corbitt, B. J., Thanasankit, T., \& Yi, H. (2003). Trust and e-commerce: a study of consumer perceptions. Electronic commerce research and applications, 2(3), 203-215.

Corritore, C. L., Kracher, B., \& Wiedenbeck, S. (2003). On-line trust: concepts, evolving themes, a model. International Journal of Human-Computer Studies,58(6), 737-758.

Daniel, E. (1999). Provision of electronic banking in the UK and the Republic of Ireland. International Journal of bank marketing, 17(2), 72-83.

Davis, F. D., Bagozzi, R. P., \& Warshaw, P. R. (1989). User acceptance of computer technology: a comparison of two theoretical models. Management science, 35(8), 982-1003.

Delafrooz, N. Rostami, F. \& Karami, R. (2013).Survey of related factors on customer trust and tendency to use banking services. Bank Marketing Articles.

Doney, P. M., \& Cannon, J. P. (1997). An examination of the nature of trust in buyer-seller relationships. the Journal of Marketing, 61(2), 35-51. 
Egger, F. N. (2001, June). Affective design of e-commerce user interfaces: How to maximise perceived trustworthiness. In Proc. Intl. Conf. Affective Human Factors Design (pp. 317-324).

Ghane, S. O. H. E. I. L. A., Fathian, M., \& Gholamian, M. R. (2011). Full relationship among esatisfaction, e-trust, e-service quality, and e-loyalty: The case of Iran e-banking. Journal of Theoretical and Applied Information Technology, 33(1), 1-6.

Ha, H. Y. (2004). Factors influencing consumer perceptions of brand trust online. Journal of Product \& Brand Management, 13(5), 329-342.

Hoffman, D. L., Novak, T. P., \& Peralta, M. (1999). Building consumer trust online. Communications of the ACM, 42(4), 80-85.

Hooman, H.A. (2009). Structural Equations Model by Using LISREL Software. Tehran: SAMT Publications.

Kalakota, R., \& Whinston, A.B. (1997). Frontiers of Electronic Commerce: A Manager's Guide. Addison Wesley, 3-7.

Khaksar, S. \& Giahi, Y. (2009). A study of factors influencing customer trust in mobile payment. The First International Conference on Banking Services Marketing, Tehran, Iran.

Kamari, F., \& Kamari, S. (2012).Trust in electronic commerce: A new model for building online trust in B2C. European Journal of Business and Management, 4(10), 125-133.

Kassim, N., \& Abdullah, N. A. (2010).The effect of perceived service quality dimensions on customer satisfaction, trust, and loyalty in e-commerce settings: A Cross Cultural Analysis. Asia Pacific Journal of Marketing and Logistics, 22(3), 351 - 371.

Kim, C., Tao, W., Shin, N., \& Kim, K. S. (2010). An empirical study of customers' perceptions of security and trust in e-payment systems. Electronic Commerce Research and Applications, 9(1), 8495.

Khodadad Hosseini, S.H., Shirkhodayee, M. \& Keronaich, A. (2009). The factors affecting customer trust in ecommerce (B2C Model). Quarterly of Human Sciences Modares, 13( 2),93-118.

Lichtenstein, S., \& Williamson, K. (2006). Understanding consumer adoption of internet banking: an interpretive study in the Australian banking context.Journal of Electronic Commerce Research, 7(2), 50-66.

Mircholi, A., Rezaie Dolat Abadi, H., Jamshidi, H. \& Amani Nabi, M. (2012).The effect of e-banking services quality on online customer satisfaction and trust according to the role of bank's reputation. The First International Conference on Management, Innovation and National Production, Qom, Iran.

Mayer, R. C., Davis J. H., \& Schoorman, F. D. (1995). An integrative model of organizational trust. Academy of. Management Review, 20(3), 709- 734.

McKnight, D. H., Choudhury, V., \& Kacmar, C. (2002). The impact of initial consumer trust on intentions to transact with a web site: a trust building model.The Journal of Strategic Information Systems, 11(3), 297-323.

Mishra, U. S., Das, J. R., Pattnaik, S., \& Mohanty, A. K. (2010). Service quality attributes affecting customer satisfaction in banking sector of India. European Journal of Economics, Finance and Administrative Sciences, 24, 88-99.

Mols, N. P. (1998). The behavioral consequences of PC banking. International Journal of Bank Marketing, 16(5), 195-201.

Sanayei, A., Faraahi, A. \& Navabpour, B. (2010). Assess the factors affecting online customer trust and its impact on online purchase intention with using structural equation modeling. The First Annual Conference on Management, Innovation and Entrepreneurship, Shiraz, Iran.

Sathye, M. (1999). Adoption of Internet banking by Australian consumers: an empirical investigation. International Journal of bank marketing, 17(7), 324-334.

Shih, Y. Y., \& Fang, K. (2004). The use of a decomposed theory of planned behavior to study Internet banking in Taiwan. Internet Research, 14(3), 213-223.

Sultan, F., Urban, G. L., Shankar, V., \& Bart, Y. (2002). Determinants and role of trust in e-business: a large scale empirical study. MIT Sloan School of Management.

Teo, T.S., \& Liu, J. (2007). Consumer trust in e-commerce in the United States, Singapore, and China. The international Journal of Management Science, 35, 22-38. 
Turban, E., Lee, J., King, D., \& Chung, H.M. (2000). Electronic Commerce: A Managerial Perspective. Prentice-Hall, Upper Saddle River, NJ.

Urban, G. L., Amyx, C., \& Lorenzon, A. (2009). Online trust: state of the art, new frontiers, and research potential. Journal of Interactive Marketing, 23(2), 179-190.

Venus, D. \& Mokhtaran, M. (2002). E-banking and necessity of its development in Iran. Journal of Management, 12(67).

Nasri, W. (2011). Factors influencing the adoption of internet banking in Tunisia. International Journal of Business and Management, 6(8), p143.

Wang, Y. D., \& Emurian, H. H. (2005). An overview of online trust: Concepts, elements, and implications. Computers in human behavior, 21(1), 105-125.

Wang, H., \& Hu, Z. (2009, December). Online Trust between Inexperienced Consumers and Experienced Consumers: An Empirical Study. In Future Information Technology and Management Engineering, 2009. FITME'09. Second International Conference on (pp. 167-170). IEEE.

Walsh, G., Mitchell, V. W., Jackson, P. R., \& Beatty, S. E. (2009). Examining the antecedents and consequences of corporate reputation: A customer perspective. British Journal of Management, 20(2), 187-203.

Yousafzai, S. Y., Pallister, J. G., \& Foxall, G. R. (2003). A proposed model of e-trust for electronic banking. Technovation, 23(11), 847-860. 